denuded zone が垫められた。

(5) $25 \mathrm{Cr}-20 \mathrm{Ni}$ 系鋼での $\sigma$ 相は, 変形材では加工に よって生ずる結晶欠陥を媒介として生成しやすいとみなす ことができ，一方変形を与えないものでは生成の難易が空 孔濃度にも依存するとみなされる。

本研究を行ならにあたり，試料の溶製などに関し日本楽 器製造株式会社磐旧工場ならびに大同特殊鋼株式会社中央 研究所の好意を得心。記して謝意を表します。

\section{文献}

(1) G. J. Guarnieri, J. Miller and F. J. Vawter : Trans. ASM, 42(1950), 981.

(2) J. I. Morley and H. W. Kirkby: J. Iron Steel Inst., $172(1952), 129$.
(3) A.J.Lena and W. E. Curry: Trans. ASM, 47 (1955) , 193.

(4) S. Nenno, M. Tagaya, K. Hosomi and Z. Nishiyama : Trans. Japan Inst. Metals, 4 (1963), 222.

（5）今井勇之進，藤村全戒：日本金属学会誌,29(1965), 29.

（6）熊田健三郎：日本金属学会誌, 30(1966)，719.

(7) 能田健三郎, 辰本宏昭: 日本金属学会誌,34(1970), 706 .

(8) E.J. Dulis and G.V.Smith : Metal Progress, $62(1952), 86$.

(9) J.J.Gilman, P.K.Koh and O.Zmeska1 : Trans. ASM, 41 (1949), 1371.

(10) R.Blower and G.J.Cox : J.Iron Steel Inst., 208 (1970), 769 .

(11) 荒木弘安, 谷川久男, 藤村全戒：日本金属学会誌, 41 (1977), 73 .

（12）藤川辰一郎，平野賢一：日本金属学会会報，10 (1971), 667, 751.

\title{
18-8ステンレス鋼の $\mathrm{H}_{2} \mathrm{SO}_{4}-\mathrm{NaCl}$ 溶液中における 応力腐食割れにおよぼす水素チャージの影響*
}

\section{上出英彦**菅原 英 夫**}

Hidehiko Kamide and Hideo Sugawara : Effect of Hydrogen Charging on Stress Corrosion Cracking of 18-8 Stainless Steel in $\mathrm{H}_{2} \mathrm{SO}_{4}-\mathrm{NaCl}$ Solution. The role of hydrogen in the mechanism of stress corrosion cracking of 18-8 stainless steel has been studied under cyclic charging of the cathode and the anode in $\mathrm{H}_{2} \mathrm{SO}_{4}-\mathrm{NaCl}$ solution.

Under the cathodic charging without applied stress, the formation of $\varepsilon-$ and $\alpha^{\prime}-$ martensites in the austenite grain were confirmed by X-ray diffraction and transmission electron microscopy. These martensites were dissolved during anodic charging. The repetition of cathodic and anodic charging resulted in the formation of the corrosion striation.

On applying a stress of $70 \%$ of the yield stress, deep cracks were formed during cyclic charging, but no cracks were observed under the cathodic charging.

It is concluded that the occlusion of hydrogen will facilitate the formation of martensite, thus stress corrosion cracking be enhanced with the repetition of the formation and dissolution of martensite by cathodic and anodic charging.

(Received March 9, 1978)

\section{I. 緒言}

$\mathrm{H}_{2} \mathrm{SO}_{4}-\mathrm{NaCl}$ 溶液中に执ける 18-8 ステンンス鋼の応力


ブゼロ処理(3)の影響について検討した・この結果,予ひずみ 材の割れは加工誘起マルテンサイトの存在と良い一致が見 られ，マルテンサイト相は地のオーステナイト相より腐食 されやすいことが明らかになった。この点から予ひずみ過
程に導入されたマルテンサイト相はその後の応力腐食割れ 試験に祘ける割れの発生および伝播に強く影響するるのと 考えられる。この予ひずみ材の割れに対し, 試験時間 $20 \mathrm{~h}$ の範围内に打いて溶体化処理材には割れが観察されなかっ た。しかし，溶体化処理材に和いても20h以上の長時間 試験を行ならと割れが観察される。溶体化処理材におい $\tau$ ，降伏応力以下の負荷応力に和いても micro-yielding が和こるような場合，加工誘起マルテンサイトの形成され 
るであららことが十分に予想される。亦た孔食および䊀界 部の腐食等の局部腐食に伴ら応力集中はマルテンサイト形 成のための micro-yielding を一層促進するであるう。一 方，18-8 ステンレス鋼に水素チャージすると水素誘発、 ルテンサイト(4) (6)の形成されることが知られている。こ の観点から腐食反即で発生する水素もまたマルテンサイト 形成に関与することが予想される。

本実験では18-8 ステンレス鋼の応力腐食割れに拉上 す吸蔵水素の影響を検討することを目的とし，試料をかり 一ド状態拉よびアノード状態に繰返し保持した場合の割れ 挙動を調ベた。

\section{II. 実 験 方 法}

供試材は市販の 18-8 ステンレス鋼板(厚さ $1 \mathrm{~mm}$ ) で西 る。その化学組成 (wt\%) $18.3 \% \mathrm{Cr}, 9.0 \% \mathrm{Ni}, 0.065 \%$ $\mathrm{C}, 0.06 \% \mathrm{Mo}, 1.68 \% \mathrm{Mn}, 0.9 \% \mathrm{Si}, 0.025 \% \mathrm{P}, 0.005 \%$ Sおよび $0.06 \% \mathrm{Cu}$ であり前報(1) (3) で用いた試料と同一 組成である, 試験片は $20 \times 4 \times 1(\mathrm{~mm})$ の平行部を有する 平板引張試験片であり，酸化を防ぐため片側を封じた内径 $\phi 16 \mathrm{~mm}$ の石英管に入れ，他方からロータリーポンプで 真空に保ちながら $1100^{\circ} \mathrm{C} \times 30 \mathrm{~min}$ 溶体化処理を拉こない 石英管ごと水冷した。溶体化処理後の試験片は $1 \mathrm{~cm}^{2}$ 定 残しシリコン樹脂で被覆し， $\mathrm{H}_{2} \mathrm{SO}_{4}: \mathrm{H}_{3} \mathrm{PO}_{4}=2: 3$ の溶液 中で電解研摩を行ない実験に供した。試験片は白金対極お よび溶液排出口を取りつけたセルとともにインストロン型 引張試験機比取り付け，0.2\% 耐力の $70 \%$ の応力を真街 し，次の手顼に従って丰験を開始した。

(1) $5 \mathrm{~N} \mathrm{H}_{2} \mathrm{SO}_{4}$ 溶液を注入する $\left(\mathrm{H}_{2} \mathrm{SO}_{4}-\mathrm{NaCl}\right.$ 溶液系で 試料をカソードにすると対極側で $\mathrm{Cl}_{2}$ の放出がおこるため $\mathrm{H}_{2} \mathrm{SO}_{4}$ 溶液を用いた).

(2) ガルバノスタットにより試料をカソードにし一定時 間保持する(カソードチャージを呼ぶことにする)．

(3) 溶液を排出する。

(4) $5 \mathrm{~N} \mathrm{H}_{2} \mathrm{SO}_{4}-0.4 \mathrm{M} \mathrm{NaCl}$ 溶液を注入レ, ガルバノス タットにより試料をアノドにする(アノードチャージと 呼ぶことにする)。

(5) 溶液を排出する.

実嗝は(1)〜(5)の行程を1サイクルとしカソード電流 $\left(-0.5,-1,-2,-4,-6,-8\right.$ 呿よび $\left.-10 \mathrm{kA} / \mathrm{m}^{2}\right)$ ア， 一ド電流 $\left(+10,+15,+30,+60\right.$ 打よび $\left.+120 \mathrm{~A} / \mathrm{m}^{2}\right)$ 㧊


数を変化させる場合，全カソードチャージ時間は $8 \mathrm{~h}$ 括よ び全アノードチャージ時間は $12 \mathrm{~h}$ として 1 試料の全試験 時間が 20 h となるようにした。

\section{III. 結果および考察}

\section{1. カソードチャージの影響}

Fig.1 はカソード電流 $-10 \mathrm{kA} / \mathrm{m}^{2}$ およびアノード電流

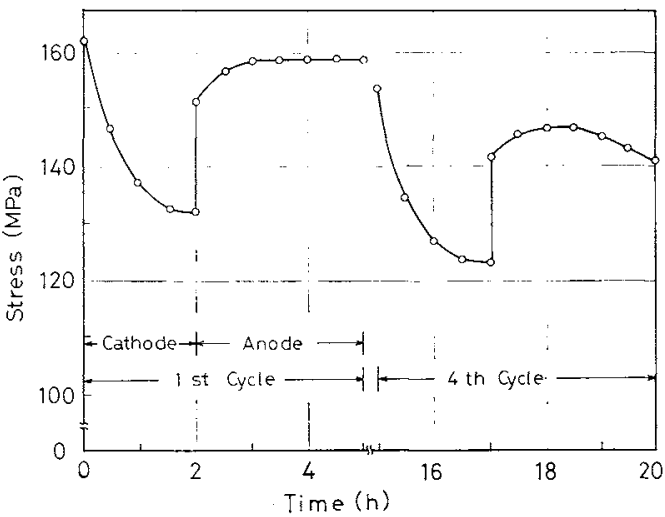

Fig.1 Stress time curve obtained from cyclic charging of 4 cycles at $-10 \mathrm{kA} / \mathrm{m}^{2}$ and $+30 \mathrm{~A} / \mathrm{m}^{2}$.

$+30 \mathrm{~A} / \mathrm{m}^{2}$ で 4 サイクル拉こなった場合の応力ー眭間曲 線である。カソードチ+ージ開始と同時に応力は急激に低 下し始める。 $-10 \mathrm{kA} / \mathrm{m}^{2}$ の場合の応力の低下は約 $1.5 \mathrm{~h}$ から緩慢になり，約 $2 \mathrm{~h}$ で活ぼ一定となる。この応力の低 下はカソード電流が大きいほど大である，溶液を除去する と応力はわずか增加する。 つづいて室温の $5 \mathrm{~N} \mathrm{H}_{2} \mathrm{SO}_{4^{-}}$ $0.4 \mathrm{M} \mathrm{NaCl}$ 溶液を注入すると応力は Fig.1に示す上5に 急激に增加しやがて一定值を示すよらになるが，0h の応 力值まで回復することはない，カソードチャージの場合， 例之ばー $10 \mathrm{kA} / \mathrm{m}^{2}$ の場合，液温はチャージ開始時に比較 して約 $12^{\circ} \mathrm{C}$ 上昇することが認められた。従ってカソード チャージ時の応力の低下はこの液温の上昇に伴ら試料の膨 張に大きく依存しているものと考光られる。サイクル数を 多くするとカソードチャージによる応力の变化は1サイク ル目の場合とほぼ同じ傾向を示すがアノードチャージによ る忘力変化は Fig.1の 4 +イクル目の場合のよ5に極大 值を示し時間とともに減少する。前報(1)で割れの発生执よ び伝播にとるない応力の減少することを示した。従って 4 サイクル目のアノードチャージにおいてはすでに割れの発 生扣よび伝播の怙こっていることが推察される。

オーステナイト鋼に水素を吸蔵させると脆化 ${ }^{(7) \sim(10) す る ~}$ ことが知られている．本実験のように応力を負荷した状態 でカソードチャージすることは水素脆性を誘発する可能性 がある，旮こでカソードチャージ単独の影響について検討


スヘッド速度で引張試験をおこなった場合の応力ーひずみ 曲線である。図中のA空気中， $\mathrm{B}$ は $5 \mathrm{~N} \mathrm{H}_{2} \mathrm{SO}_{4}$ 溶液中 (自然浸漬状態下)，Cは $5 \mathrm{~N} \mathrm{H}_{2} \mathrm{SO}_{4}$ 溶液中で $-8 \mathrm{kA} / \mathrm{m}^{2}$ に 保持した場合就よびDは $0.2 \%$ 耐力の $70 \%$ の応力を負荷し $-8 \mathrm{kA} / \mathrm{m}^{2}$ で $8 \mathrm{~h}$ カソードチャージ後 C と同じ条件で引 張試験を和こなった結果である。伸びはカソードに保持し た時間が長い場合ほど減少する。Dの試料について走査型


dimple pattern が支配的であるが表面部近傍に局部的に 


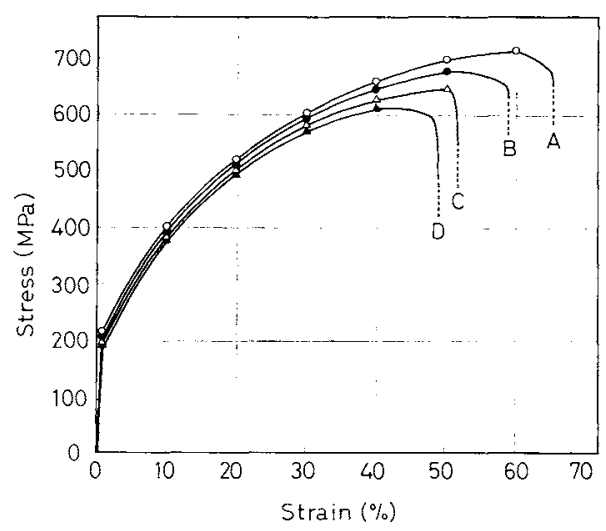

Fig.2 Stress strain curves obtained from various conditions at a cross-head speed of 0.5 $\mathrm{mm} / \mathrm{min}$. Specimens were tensile-tested (A) in air (B) in $5 \mathrm{~N} \mathrm{H}_{2} \mathrm{SO}_{4}$ solution at $E_{\text {corr }}$ and (C) in $5 \mathrm{~N} \mathrm{H}_{2} \mathrm{SO}_{4}$ solution at $-8 \mathrm{kA} / \mathrm{m}^{2}$. Specimen (D) was charged at $-8 \mathrm{kA} / \mathrm{m}^{2}$ for $8 \mathrm{~h}$ in $5 \mathrm{~N} \mathrm{H}_{2} \mathrm{SO}_{4}$ solution under $70 \%$ of the $0.2 \%$ proof stress and then tensile-tested under cathodic charging.

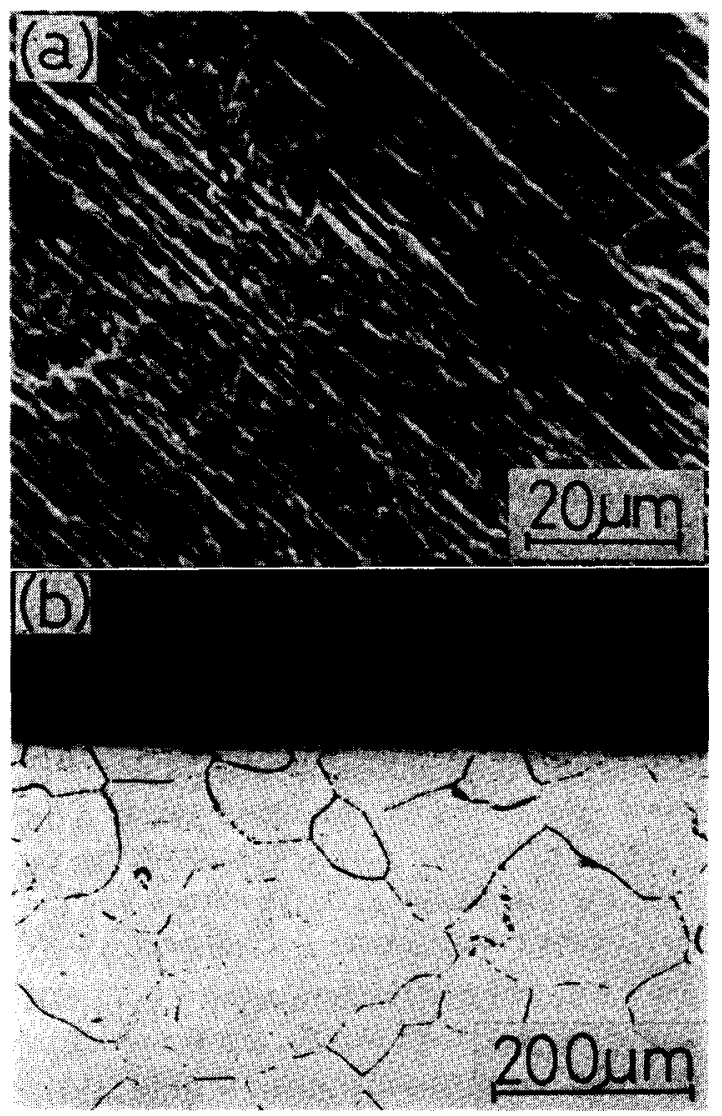

Photo.1 Scanning electron micrograph and optical micrograph after cathodic charging under $70 \%$ of the $0.2 \%$ proof stress in $5 \mathrm{~N} \mathrm{H}_{2} \mathrm{SO}_{4}$ solution.

(a) surface morphology of specimen charged at $-10 \mathrm{kA} / \mathrm{m}^{2}$ for $8 \mathrm{~h}$.

(b) cross section of specimen charged at $-10 \mathrm{kA} / \mathrm{m}^{2}$ for $20 \mathrm{~h}$.
脆性破面に類似した破面観察された。この点を明らか炕 することはできなかったが，18-8ステンレス鋼はカソー ドと保持しながら引張試験を括こならと伸びの隇少するこ とがわかる．本実験は降伏応力以下の負荷応力のもとでの 実験を目的とするが，上述の事実を考虑に入れて次の実験 を和こなった，Photo.1は静的な応力負荷状態でカソー ドチャージした場合の結果である．Photo.1(a)は $0.2 \%$ 耐 力の $70 \%$ の応力負荷下でー $10 \mathrm{kA} / \mathrm{m}^{2}$ に $8 \mathrm{~h}$ 保持した場合 の表面のSEM写真である，写真左上から右下に互いに平 行に走る溝が多く観察される.Photo 1(b)は同条件で $20 \mathrm{~h}$ 保持した場合の試料断面の顕微鏡写真である。割れおよび 表面に観察される溝状の形態は全く観察されない。このこ とから Photo.1(a)の輔はごく表面層に限られた浅いもの と考えられる。これら满の形成機構を明らかにすることは できなかったが考竞られることは第1に水素を吸蔵するこ とによってのみ形成されること, 第 2 に緑川等(11) 合金のカソード焀食について調べ, pH 1.25 の硫酸酸性溶 液中に和いて，例えば $\mathrm{Fe}-14 \% \mathrm{Cr}$ 合金は自然浸清電位よ り約 $100 \mathrm{mV}$ 卑な電位に叔いて子 1 時間当り $2.5 \mathrm{~g} / \mathrm{m}^{2}$ の腐食速度を示すことを報告している。本実験で用いた $5 \mathrm{~N} \mathrm{H}_{2} \mathrm{SO}_{4}$ 溶液の $\mathrm{pH}$ は約 0.35 であり，上述の実験条件 とは多少異なるが定珄的には水素発生反応は一層貴側に移 行するでめろらことおよびカソードチャージにより液温の 上萛することからカソードチャージ下でも鹰食する可能性 のあること，第 3 以暴相が存在する場合に脽食举動が顕著 になること，の3点であらう，18-8ステンレス锎に水素 チャージすると水素吸藏の結果，水素誘発マルテンサイ

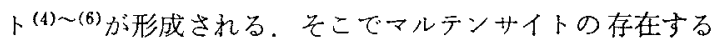
試料についてカソードチャージした場合の表面観察を和 こなった．Photo.2は溶体化処理後の試料を液体窒素 $\left(-196^{\circ} \mathrm{C}\right)$ 中にサブゼロ処理を抗こない，電解研杽のらち 応力を負街することなく $-2 \mathrm{kA} / \mathrm{m}^{2}$ で $8 \mathrm{~h}$ カソードチャ ージした試料の表面状態である，表面には $\alpha^{\prime}$ マルテンサ イトに対応 ${ }^{(3)}$ する部分に起优の生じているのが観察され る、つづいて次の契験を执こなった，溶体化処理材および



Photo.2 Surface morphology of specimen charged at $-2 \mathrm{kA} / \mathrm{m}^{2}$ for $8 \mathrm{~h}$ after subzero treatment. 
溶体化処理後 $-196^{\circ} \mathrm{C}$ にサブゼロ処理した試料は電解研摩 ののち $60 \mathrm{cc} の 5 \mathrm{~N} \mathrm{H}_{2} \mathrm{SO}_{4}$ 溶液中で $9 \mathrm{~h}$ カソードチャージ を和こない，溶液中に溶出した Feイオン量をオルトフェ ナントロリン法によって分析した。 Table 1 は 2 種類の カソード電流によってチャージを抢こなった場合の溶体化 处理材拉よびサブゼロ材の溶出全 Fe イオン量である，Fe イオンの溶出速度の実測は抗こなわなかったが全溶出 $\mathrm{Fe}$ イオンに関する限り，カッードチャージ中にも Fe イオン の溶出することがわかる。溶出 Fe イオン量は溶体化処理 材くサブゼロ材和上びー $3 \mathrm{kA} / \mathrm{m}^{2}<-6 \mathrm{kA} / \mathrm{m}^{2}$ である。 これらの結果から Photo.1(a)および Photo.2 の表面状態 はカソードチャージ中に合金の構成成分の溶出によって生 じることも考光られる。カンードチャージの操作は陰極防 食を意味するにもかかわらず，溶出した Fe イオンが認め ら礼る。18-8 ステンレス鋼は水素吸藏によってマルテン サイトを形成するが卌素の吸収量および拡散速度は各相に よって異なる。この観点から微視的な鋼の性質変化々水素 の吸収扣よび抾散挙動の相違によって特有の場所が溶出乙 易くなるとも考光られるが現段階ではとれを明らかにする ことができなかった．Photo.1(a)の溝の形式は本実験の ような割れ試験においてはすでにカソードチャージの段階 で割れの発生の初期過程が表面で形成されていることを示 す.
Table 1 Iron analysis of $5 \mathrm{~N} \mathrm{H}_{2} \mathrm{SO}_{4}$ solution after cathodic charging for $9 \mathrm{~h}$.

\begin{tabular}{l|c|c}
\hline & $-3\left(\mathrm{kA} / \mathrm{m}^{2}\right)$ & $-6\left(\mathrm{kA} / \mathrm{m}^{2}\right)$ \\
\hline Solution treatment & 26.36 & 62.15 \\
Subzero treatment & 30.37 & 108.72 \\
\hline
\end{tabular}

$\left(\mathrm{g} / \mathrm{m}^{2}\right)$

\section{2.チャージ繰返しの影響}

割れにおよ济すカソードチャージおよびアノードチャー シの絽返しの影偣について検討した，Photo.3はカソード 電流 $-10 \mathrm{kA} / \mathrm{m}^{2}$ およびアノード電流 $+30 \mathrm{~A} / \mathrm{m}^{2}$ の条件で 繰返し数 $1,2,4$ 执よび 8 サイクルとした場合の結果であ る。1サイクルの場合は割れおよび腐食溝は観察されない のに対し 2 サイクルで注浅い腐食溝が観察される。これに 対し 4 および 8 サイクルの場合は明確な割れが観察され， 両者の割れ深さは類似する。Fig.1の4サイクル目に特い てアノードチャージの段階で応打の減少が観察された。こ の応力の低下は局部的に塑性変形することによって応力の 緩和(1)が怙こるものと考えられるのでチャージを繰返しお こない，割れが発生するとアノードチャージの過程です割 れの先端では塑性变形を叔こすうになる。このようにカ ソードチャージの効果に塑性变形挙動が重複されるため 4 および8サイクルの割れ深さに差異が涊奶られなくなるも



Photo.3 Effect of cyclic charging on stress corrosion cracking. $(\times 100)$
(a) 1 cycle,
(b) 2 cycles,
(c) 4 cycles
(d) 8 cycles.
Experimental condition : cathodic current $=-10 \mathrm{kA} / \mathrm{m}^{2}$ anodic current $=+30 \mathrm{~A} / \mathrm{m}^{2}$ 




Photo.4 Effect of anodic charging on stress corrosion cracking. $(\times 100 \times 2 / 3)$ (a) $+10 \mathrm{~A} / \mathrm{m}^{2}$, (b) $+60 \mathrm{~A} / \mathrm{m}^{2}, \quad$ (c) $+120 \mathrm{~A} / \mathrm{m}^{2}$

Experimental condition : cathodic current $=-10 \mathrm{kA} / \mathrm{m}^{2}$ cycle $=4$
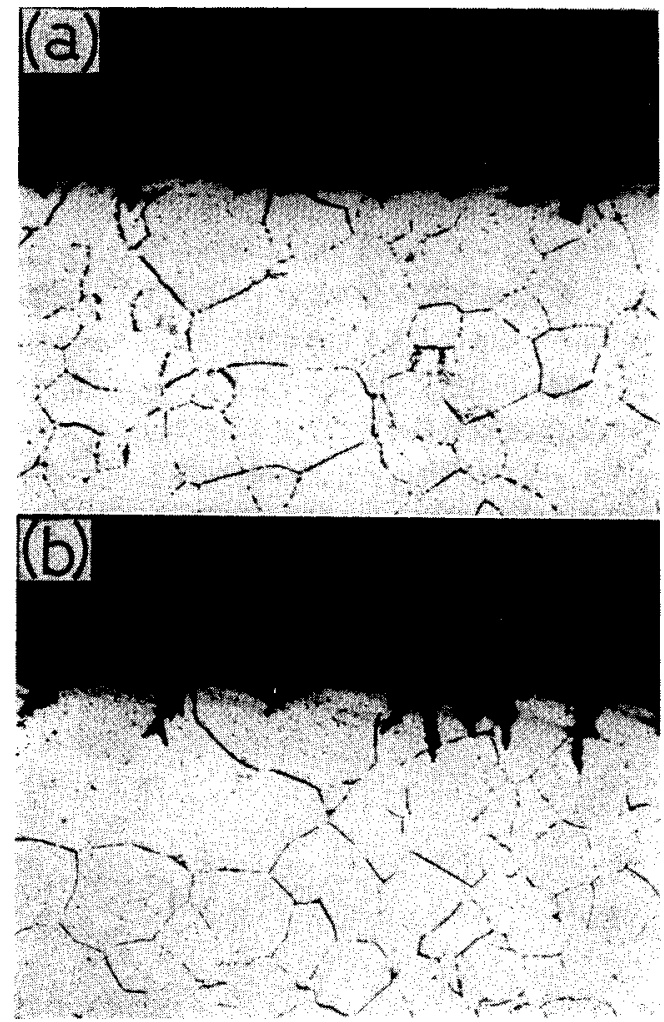

Photo.5 Effect of cathodic charging on stress corrosion cracking. $(\times 100)$
(a) $-0.5 \mathrm{kA} / \mathrm{m}^{2}$
(b) $-6 \mathrm{kA} / \mathrm{m}^{2}$
Experimental condition : anodic current $=+30 \mathrm{~A} / \mathrm{m}^{2}$
cycle $=4$

のと考觉られる。Photo.4 はカソード電流 $-10 \mathrm{kA} / \mathrm{m}^{2}$ 抹 よびサイクル数 4 の条件でアノード電流を $+10,+60$ 抢よ び+120 $\mathrm{A} / \mathrm{m}^{2}$ 变化させた場合である。割れは +10 蛙よ び+60A/m² の条件で観察される。+120 A/m $\mathrm{m}^{2}$ の場 合，写真左側の平滑面は被覆部で苟り，写真右側の平滑面 は露出部である．全面腐食に上る著しい減肉と腐食渾が観 察される。この全面腐食举動は $+60 \mathrm{~A} / \mathrm{m}^{2}$ に和いて若 干観察される。アノード電流を変化させた場合の割れは +15〜+30 A/m² で顕著であった. Photo.5はアノード 電流 $+30 \mathrm{~A} / \mathrm{m}^{2}$ 打よびサイクル数 4 の条件でカソード電
流を一 $0.5 \mathrm{kA} / \mathrm{m}^{2}$ およびー $6 \mathrm{kA} / \mathrm{m}^{2}$ とした場合である。 $-0.5 \mathrm{kA} / \mathrm{m}^{2}$ の場合は浅い腐食满が観察されるのに対し， $-6 \mathrm{kA} / \mathrm{m}^{2}$ の場合には割れが観察される・割れはカッード 電流に比例して樑くなる傾向が琶められた。Photo.3〜 Photo.5 からカソードチャージ単独 (Photo.1)の場合に割 れは観察されないのに対しアノードキャージを結返すこと によって割れとなることがわかる。

前報 (2)(3)で 18-8 ステンレス鋼のこの系の割れは子ひず み過程で導入された欠陥，特に加工誘起マルテンサイトと 関係していることを述べた。この点からカソードチャージ の段階で材料内部に欠宿の導入，特にマルテンサイトが形 成されているとすれ洼かyード拉よびアノードチャージを 繰返すことによって割れの発生することが理解できる。

Fig.3 は溶体化処理後，電解研摩を和こなった18-8ステ ンレス鍋に応力を負荷することなく $5 \mathrm{~N} \mathrm{H}_{2} \mathrm{SO}_{4}$ 溶液中で $-0.5 \mathrm{kA} / \mathrm{m}^{2}$ 敊よびー $6 \mathrm{kA} / \mathrm{m}^{2}$ の条件で $8 \mathrm{~h}$ 保持した試 料から得たX線回折結果である.X線回折は理学電機の口 一ターフレックスを用い，回折条件はCo ターゲット，電圧 $45 \mathrm{kV}$ および電流 $160 \mathrm{~mA}$ である。いずれの場合もとお

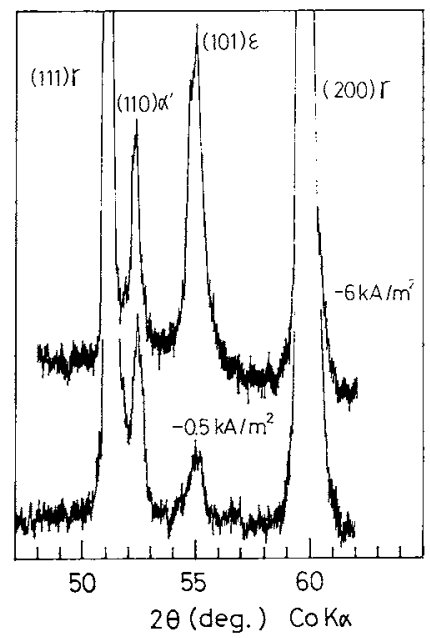

Fig.3 X-ray diffraction patterns after cathodic charging at $-0.5 \mathrm{kA} / \mathrm{m}^{2}$ and $-6 \mathrm{kA} / \mathrm{m}^{2}$ in $5 \mathrm{~N} \mathrm{H}_{2} \mathrm{SO}_{4}$ solution for $8 \mathrm{~h}$. 
よび $\alpha^{\prime}$ マルテンサイトの存在が認められ. Holzworth ${ }^{(4)}$ および蒲地(5)等と同じ結果を得た。Photo.6はカソード チャージした薄膜試料の透過電子顕微鏡写真である。薄膜 は20 min 俚上げ研摩(仕上げ研摩完了に約 30 35 min 要する)をおこなったのら約 $-1 \mathrm{kA} / \mathrm{m}^{2}$ で $8 \mathrm{~h}$ カソードチ ャージし，つついて仕上げ研摩を完了し薄膜を作製した。 多くの積層欠陥も観察されるが電子線回折の結果 $\varepsilon$ マルテ ンサイトに対応する回折斑点舟認められ，カソードチャー

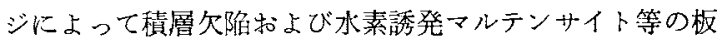
状組織が形成される。しかし，これら板状組織は20 $\mathrm{min}$ 以下の短時間仕上げ研摩の場合，すなわらカソードチャー ジ後の再仕上げ研摩持間が長い場合には観察されなかっ た。この点から板状組織はかなり表面層にかぎれて形成 されるものと考光られる。

Photo. 3 から溶体化処理材に拉いて $20 \mathrm{~h}$ といら試験 時間内にカソードおよびアノードチャージを繰返すことに より割れが発生しここの時の割れ挙動は繰返し数に強く影 製されることが明らかになった。しかし，Fig.1からカン ードチャージすると応力の低下が和こり，つついて室温の

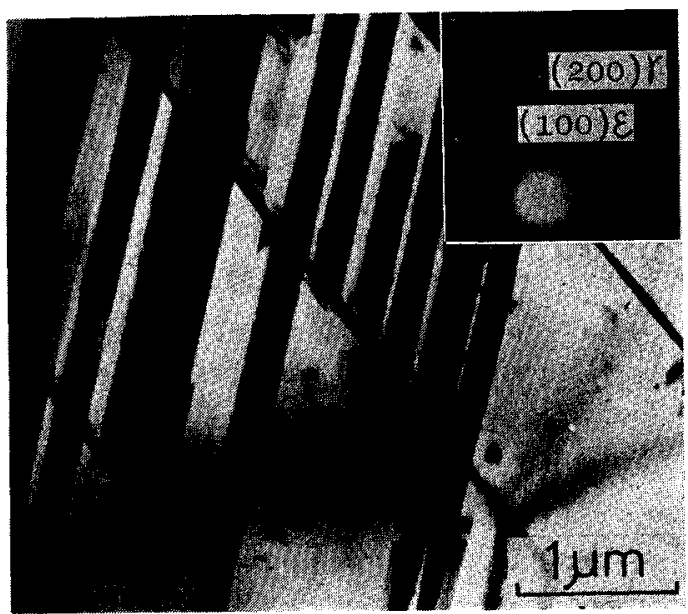

Photo.6 Transmission electron micrograph of thin foil specimen charged at $-1 \mathrm{kA} / \mathrm{m}^{2}$ in $5 \mathrm{~N} \mathrm{H}_{2} \mathrm{SO}_{4}$ solution for $8 \mathrm{~h}$.
溶液を注入すると応力は上㫒する。この点からカソードお よびアノードチャージを繰返すことは繰返し応力の効果も また関与することになる。この点を検討するため，応力無 負佰の状態でカソード乱びアノードチャージの繰返しを 括こなった.Photo.7は繰返しチャージを拉こなった場 合の表面 SEM 写真である. Photo.7(a)は-2kA/m² で $8 \mathrm{~h}$ 保持した場合, Photo.7(b)は+15 A/m² 持した場合である。カソードチャージの場合, 電解研摩に よる平滑面が支配的であるが部分的に Photo.7(a)のよう なフっ七ット溶解に似た表面が観察される。アノードチ十 一ジの場合は粒界部の腐食と粒内にマイクロピットが観察 される.Photo.7 (c) は同じカソード执よびアノード電流 で8サイクル(1サイクルのカソードチャージは 1 h およ びアノードチャージは $1.5 \mathrm{~h}$ ) 繰返しチャージをおこなっ た場合である。粒内に無数の腐食菙が観察され，たがいに 平行である，応力無鱼荷の状態に拈いてるカソードおよび アノードチャージを繰返すことによっで腐食淟が形成され る。こ礼らの腐食溝の形成理由は不明であるが現段階では 次のよらに考光られる。カソードチャージ中に積層欠陥拉 よびマルテンサイト等の板状組織が表面層に形成され，つ つくアノードチャージ中に特有の相が選択的に溶解する。

これらを程返すことによってカソードチャージ過程で新た に形成された相が溶解し Photo.7(c)に示す腐食潔が形成 されるるのと考えられる。

上述の結果は強制的なカソードチャージによって水素誘 発マルテンサイトの形成される条件下の試験である。自然 浸清下に打ける水素誘発マルテンサイト形成の可能性につ いて铪討を加えた。 Fig.4は $5 \mathrm{~N} \mathrm{H}_{2} \mathrm{SO}_{4}-0.4 \mathrm{M} \mathrm{NaCl}$ 溶液 中(非脱気 $\left.25^{\circ} \mathrm{C}\right)$ に抬ける18-8 ステンレス鈮の分極曲線で ある、测定は $20 \mathrm{mV} / 10 \mathrm{~min}$ の条件によるステップ法で おこなった。Tafel 勾配の交点から自然浸漬状態に打ける 腐食電流が求まり，その值は約 $5.7 \mathrm{~A} / \mathrm{m}^{2}$ である。Fig.5 は $5 \mathrm{~N} \mathrm{H}_{2} \mathrm{SO}_{4}-0.4 \mathrm{M} \mathrm{NaCl}$ 溶液中で一6 $\mathrm{A} / \mathrm{m}^{2}$ および $-60 \mathrm{~A} / \mathrm{m}^{2}$ で $50 \mathrm{~h}$ カソードチャージした場合のX線回 折結果である。 $-60 \mathrm{~A} / \mathrm{m}^{2}$ の場合は $\varepsilon$ および $\alpha^{\prime}$ マルテ


Photo.7 Surface morphologies of specimen charged at various conditions without applied stress.

(a) at $-2 \mathrm{kA} / \mathrm{m}^{2}$ for $8 \mathrm{~h}$.

(b) at $+15 \mathrm{~A} / \mathrm{m}^{2}$ for $12 \mathrm{~h}$.

(c) 8 cycles at $-2 \mathrm{kA} / \mathrm{m}^{2}$ for $1 \mathrm{~h}$ and $+15 \mathrm{~A} / \mathrm{m}^{2}$ for $1.5 \mathrm{~h}$. 


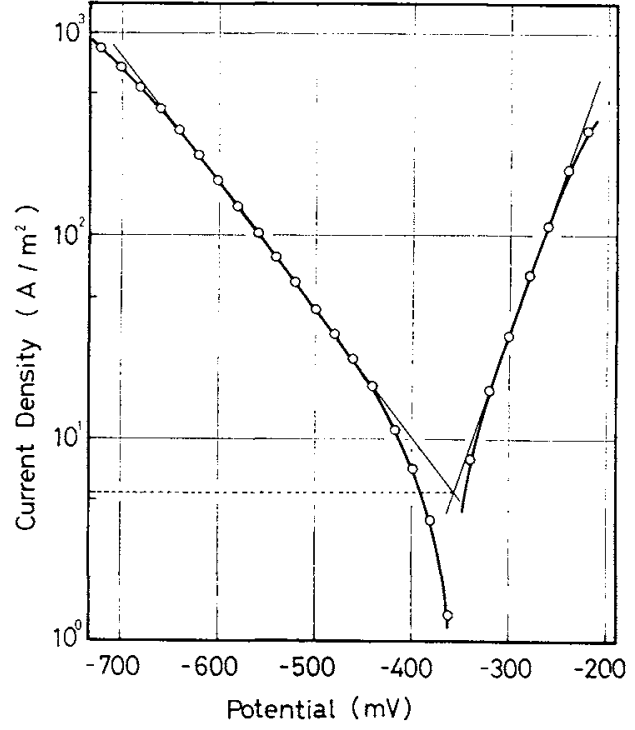

Fig.4 Polarization curve of 18-8 stainless steel in $5 \mathrm{~N} \mathrm{H}_{2} \mathrm{SO}_{4}-0.4 \mathrm{M} \mathrm{NaCl}$ solution.

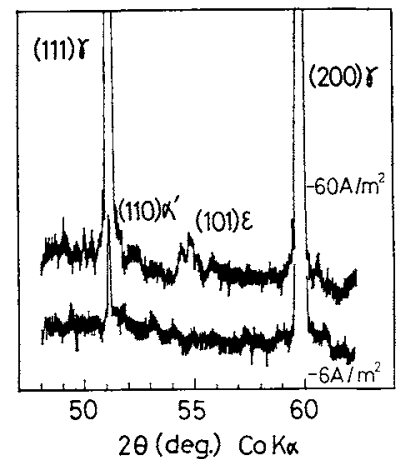

Fig.5 X-ray diffraction patterns after cathodic charging at $-6 \mathrm{~A} / \mathrm{m}^{2}$ and $-60 \mathrm{~A} / \mathrm{m}^{2}$ in $5 \mathrm{~N} \mathrm{H}_{2} \mathrm{SO}_{4}-0.4 \mathrm{M} \mathrm{NaCl}$ solution for $50 \mathrm{~h}$.

ンサイトの回折ピークを認めることができるが，Fig.4か ら自然浸清下のカンード反応に相当すると思われる -6 A/m²でカッードチャージした場合はマルテンサイト の存在を認めることができなかった。しかし局部的にカン 一ド反枕部の強弱が生じるような場合には部分的に -6 A/m² 越光るカソード反応部の形成されることも 予想される。一方, Holzworth(4) はオーステナイト鋼に 本素チャージすると積周欠陥エネルギーの低下することを 示し，樻層欠宿エネルギーの低下はマルテンサイト变態を おこしやすいであううことを指摘(4)(12)した。本実験で用 いた18-8 ステンレス鎆はマルテンサイト変態を拉こしや すい材料であり，降伏応力以下の負荷応力に沶いても micro-yielding によってマルテンサイト变態の怙こるこ とが予想される。このような状態下で自然浸清腐食中に発 生した我素が積層欠陮エネルギーの低下を引き和こすよう な場合，あるいは格子にひずみをあた党るような場合、、
ルテンサイト変態は一層促進されるものと考壳られる。

以上の点から自然浸清腐食中に打放生水素量るマル テンサイトの形成に大さく奇与するものと推論される。

Fe-Cr-Ni 系オーステナイトステンレス鋼のうち 18-8 系ステンレス鋼がもっとも割れやすいのは，耐食性の問題 を考慮に入れず材料内部の問題からのみ推測すると，前 報(1) (3) の結果からこの鋼はマルテンサイトを形成しやす いためと考えられる。上述の結果から，溶体化処理材に物 いても micro-yielding 引引执こす伈力の効果に加克て 我素を発生する環境下に和いては吸蔵水素の効果によって マルテンサイトの形成は一層容易になる. Photo.3およ び Photo.7 から腐食溝および割れはカソード拉よびア， ードチャージを繰返すことによって形成される。この割れ はカッードチャージによって水素誘発マルテンサイトが形 成され，つつくくアノードチャージによってこのマルテンサ イトが溶解することの繰返しおよび Fig.1の4サイクル 目のアノードチャージで㤁力の緩和がおこることから塑性 変形の導入に伴うマルテンサイトの形成と溶解とによって 形成されるものと考党られる。この観点から 18-8 ステン レス銅のこの系の割れはマルテンサイトの形成と溶解の繰 返しによって促進されるものと考えられる。

\section{IV. 結矛}

18-8 ステンレス鋼の $\mathrm{H}_{2} \mathrm{SO}_{4}-\mathrm{NaCl}$ 系溶液中の応力腐食 割れに和よ济すカソード括よびアノードチャージ繰返しの 影響について検討した結果，次の結論を得た。

(1) カソードチャージおよびアノードチャージを繰返す と割れが発生し，割れの深さは繰返しのサイクル数に依存 する。サイクル数が同じ場合，割れはカソード電流の大き い注どまたアノード電流は+ $15 \mathrm{~A} / \mathrm{m}^{2} \sim+30 \mathrm{~A} / \mathrm{m}^{2}$ で もっとも深い。

(2) X線回折の結果，カソードチャージするとをおよび $\alpha^{\prime}$ マルテンサイトが形成され， $5 \mathrm{~N} \mathrm{H}_{2} \mathrm{SO}_{4}-0.4 \mathrm{M} \mathrm{NaCl}$ 溶 液中に拁いては $-60 \mathrm{~A} / \mathrm{m}^{2}$ のカソード電流で両マルテン サイトの存在が認められる。

(3) 18-8 ステンレス鋼のこの系の割礼はマルテンサイ トの形成と溶解の繰返しによって促進されるものと考光ら れる。

終りに本実験をおこならにあたり御助言をいただいた日 本製鋼所空蘭製作所 大西敬三博士に心から感謝いたしま す。季たX線回折の測定に御協力いただいた理学電気 $\mathrm{KK}$ の方々に感謝いたします。

\section{文南}

（1）上出英彦，菅原英夫：日本金属学会誌，40(1976)， 946 .

（2）上出英彦，菅原英夫：日本金属学会誌，40(1976), 1243 
（3）上出英彦，菅原英夫：日本金属学会誌，41 (1977)， 528.

(4) M. L. Holzworth and M. R. Louthan Jr., : Corrosion, 24(1968), 110.

（5）蒲地一義，宮田節夫, 衛藤正美：日本金属学会誌, $33(1969), 824$.

（6）蒲地一義，婥 睦：防食技術，24(1975)，641。

(7) P.B.Benson Jr., R. K. Dann and L.W. Roberts Jr. : Tranrs. Met.Soc. AIME, 242 (1968), 2199.
(8) M.B.Whiteman and A.R.Troiano: Corrosion, $21(1965), 53$.

(9) M.L.Holzworth: Corrosion, 25(1969), 107.

（10）野村茂雄; 長谷川正義：日本金属学会会報，15 (1976) , 563.

(11) 緑川林造, 石川達雄, 能登谷武紀, 瀬野尾正久：電 気化学協会講演要旨集, (1969), A 22 .

(12) J. F. Breedis : Trans. Met. Soc. AIME, 230 (1964), 1583.

\section{$\mathrm{Na}_{2} \mathrm{O}-\mathrm{GeO}_{2}$ ガ ラ ス の 構 造}

\section{岩 本 信 也* 梅 咲 則 正**}

Nobuya Iwamoto and Norimasa Umesaki : The Structure of $\mathrm{Na}_{2} \mathrm{O}-\mathrm{GeO}_{2}$ Glasses. In order to clarify the structural change in $\mathrm{GeO}_{2}$ glass due to the addition of alkali metal oxides, the radial distribution functions for $\mathrm{Na}_{2} \mathrm{O}-\mathrm{GeO}_{2}$ glasses containing $0,10,20 \mathrm{~mol} \% \mathrm{Na}_{2} \mathrm{O}$ were determined by $\mathrm{X}$-ray diffraction measurement.

The results are summarized as follows:

(1) The structure of $\mathrm{GeO}_{2}$ glass was composed of tetrahedral $\mathrm{GeO}_{4}$ basic structural units with an average $\mathrm{Ge}-\mathrm{O}$ distance of $1.74 \times 10^{-10} \mathrm{~m}$. The average structure of $\mathrm{GeO}_{2}$ glass in the short range resembled that of the quartz modification.

(2) Analysis of the radial distribution functions indicated that oxygen coordinations around some of $\mathrm{Ge}^{4+}$ ions in $\mathrm{Na}_{2} \mathrm{O}-\mathrm{GeO}_{2}$ glasses changed from $\mathrm{GeO}_{4}$ tetrahedra to $\mathrm{GeO}_{6}$ octahedra when $\mathrm{Na}_{2} \mathrm{O}$ was added up to $20 \mathrm{~mol} \%$.

(Received March 14, 1978)

\section{I. 緒言}

代表的ガラス形成酸化物の1つであるゲルマン酸塩 $\left(\mathrm{GeO}_{2}\right)$ は, $\mathrm{GeO}_{4}$ 四面体を基本構造単位とする 3 次元的ネ ットワク構造から成り，珄酸盐 $\left(\mathrm{SiO}_{2}\right)$ ガラスと類似して いることが知られている。この $\mathrm{GeO}_{2}$ ガラスにアルカリ金 属酸化物 $\left(\mathrm{M}_{2} \mathrm{O}\right)$ を添加した場合， $\mathrm{M}_{2} \mathrm{O}-\mathrm{SiO}_{2}$ ガラスとは異 なる挙動を示すことが，従来の密度 ${ }^{(1)}$, 屈折率 ${ }^{(2)}$, 赤外吸 収スペタトル(2)(3), 内部摩擦(4)等の測定から報告されてい ろ. 特に密度 ${ }^{(1)}$, 屈折率 ${ }^{(2)}$, 内部摩擦 ${ }^{(4)}$ の測定の場合, $\mathrm{M}_{2} \mathrm{O}$ 添加量に依存して, これらの測定值が極大を示すこと が指摘されてきた。去の原因として，ダルマニアに対する 酸素の配位数が 4 から 6 への变化，すなわち $\mathrm{GeO}_{4}$ 四面 体から $\mathrm{GeO}_{6}$ 八面体への変化と，過剩に供給される酸素に よる 3 次元的ネットワーク構造の破壊により形成された非 架橋酸素に関係することが論じられてきた。しかしながら， これら測定値からの構造解析は問接的なものである。

一方, X線拉よび中性子回折実験からの構造解析は, 值 接ガラス中に和计る原子配列関する知見，すなわち原子 の分布関数が得られる。この分布関数は，ガラス構造を解 明する上で貴重な情報である。しかしながら，従来のX線
および中性子回折実験による構造解析の報告は $\mathrm{GeO}_{2}$ ガラ ス(5) (9)に限られて括り， $\mathrm{M}_{2} \mathrm{O}-\mathrm{GeO}_{2}$ ガラスの組成と構造 についての関連性を回折実験から求めた例は見当らない， そこで，本研究は代表的な $\mathrm{Na}_{2} \mathrm{O}-\mathrm{GeO}_{2}$ ガラスの $2,3 の$ 組成と檴造についての関連性を動径分布関数(RDF， Radial Distribution Function)により検討した。

\section{II. 試料作製および実験方法}

\section{1. 試料作製}

三津和化学製の $\mathrm{GeO}_{2}$ 粉末(純度 7-N min) と, 和光純薬 製の $\mathrm{Na}_{2} \mathrm{CO}_{3}$ 粉末 (試薬特級) を所定の組成に混合し，大気 中雾囲気で所定時間溶解後，ただちに空冷することにより ガラス陚料を作製した，得られたガラス試料の表面を平䶤 に研摩し，約 $20 \times 20 \times 3 \mathrm{~mm}$ の平板をX線回折実験用試 料とした。また，ガラス試料の密度測定にはトルェンを用 いたアルキメデス法を採用した。

Table 1 とガラス試料の作製条件掞よび実測密度を示 t.

\section{X線回折実験}

測定には理学電機製氷平式ゴニオメーターX線回折装置

* 大阪大学溶接工学研究所 (Welding Research Institute, Osaka University, Suita)

***大阪大学大学院 (Graduate School, Osaka University, Suita) 